\title{
Health education to prevent chronic diabetes mellitus complications in primary care ${ }^{a}$
}

\author{
Educação em saúde para prevenção das complicações crônicas do diabetes mellitus na atenção primária \\ Educación en salud para la prevención de las complicaciones crónicas de diabetes mellitus en la
}

Maria Aparecida Salci ${ }^{1}$

Betina Hörner Schlindwein Meirelles ${ }^{2}$ Denise Maria Guerreiro Vieira da Silva²

1. Universidade Estaudal de Maringá. Maringá, PR, Brazil

2. Universidade Federal de Santa Catarina.

Florianópolis, SC, Brazil a Extracted from a thesis entitled "Primary Health Care and prevention of chronic complications in people with diabetes mellitus in light of the complexity", defended in 2015, in the Graduate Studies Program in Nursing of the Federal University of Santa Catarina (UFSC).

\section{Corresponding author:}

Maria Aparecida Salci.

Email: masalci@uem.br

Submitted on $08 / 22 / 2017$.

Accepted on 10/16/2017.

DOI: 10.1590/2177-9465-EAN-2017-0262

\section{Abstract}

Objective: Understand how Family Health Strategy members organize themselves for health education, on the management and prevention of chronic complications of diabetes mellitus in primary health care. Method: Qualitative study that used complex thought as the theoretical framework and evaluative research as the methodological framework. Thirty-eight healthcare professionals took part in the study. Data was gathered using the following techniques: interview, observation, and analysis of medical records. The data analysis, which was supported by triangulation, used ATLAS.ti software. Results: Shortcomings in health education were identified, such as insufficient infrastructure, poor interpersonal relationships among health professionals, and lack of planning for carrying out this activity. However, there is room for potential improvement in this situation. Conclusion: Health education for people with diabetes mellitus in primary health care is set within a multifaceted context, with multiple barriers to its implementation.

Keywords: Diabetes mellitus; Diabetes complications; Primary health care; Health education; Health services evaluation.

\section{Resumo}

Objetivo: Compreender como os integrantes da Estratégia Saúde da Família se auto-organizam para a educação em saúde, no manejo e prevenção das complicações crônicas do diabetes mellitus na Atenção Primária à Saúde. Método: Estudo qualitativo que utilizou o Pensamento Complexo como referencial teórico e a pesquisa avaliativa como referencial metodológico. Participaram da pesquisa 38 profissionais de saúde. Para a coleta de dados utilizou-se: entrevista, observação e análise de prontuários. A triangulação subsidiou a análise dos dados e empregou-se o software ATLAS.ti. Resultados: Foram identificadas fragilidades na realização da educação em saúde referentes à estrutura física, nos relacionamentos interpessoais entre os profissionais e ausência de planejamento para implementação dessa atividade. Entretanto, apontaram espaços considerados potenciais para a melhoria dessa realidade. Conclusão: Considera-se que a prática da educação em saúde para as pessoas com diabetes mellitus na Atenção Primária à Saúde compõe um contexto multifacetado, com múltiplas barreiras para sua execução.

Palavras-chave: Diabetes mellitus; Complicações do Diabetes; Atenção Primária à Saúde; Educação em Saúde; Avaliação de Serviços de Saúde.

\section{REsumen}

Objetivo: Comprender cómo los participantes del Programa Estrategia Salud de la Familia se organizan en relación con la educación en salud, en la gestión y prevención de las complicaciones crónicas de la diabetes mellitus en la Atención Primaria a la Salud. Método: Estudio cualitativo que utilizó Pensamiento Complejo como marco teórico y investigación evaluativa como marco metodológico. Participaron 38 profesionales de salud. Los datos se obtuvieran mediante: entrevista; observación; análisis de los registros médicos. El análisis de datos se apoyó en la triangulación, con el software ATLAS.ti. Resultados: Se identificaron debilidades relativas a la educación en salud, como falta de estructura física, relaciones interpersonales entre profesionales y ausencia de una planificación para ejecutar esta actividad. Sin embargo, hay espacio para una mejora potencial de esta situación. Conclusión: La práctica de la educación para la salud de personas con diabetes en Atención Primaria constituye un contexto de múltiples facetasy obstáculos.

Palabras clave: Diabetes Mellitus; Complicaciones de la Diabetes; Atención Primaria a la Salud; Educación en Salud; Evaluación de Servicios de Salud. 


\section{INTRODUCTION}

The complexity of the health/disease process of diabetes mellitus (DM), which is noted for its significant prevalence, high morbidity and mortality, and immense costs to sufferers, family members, society and health systems, requires providing people with knowledge to enable adequate management of the disease. ${ }^{1-3}$ Among the public policies for DM and international consensuses, one important duty of health professionals, especially those in primary health care $(\mathrm{PHC})$, is carrying out health education activities, both individually and collectively for people with DM. ${ }^{2,4,5}$

This requires breaking away from traditional pedagogical concepts and approaches that have prevailed in educational processes. The most recommendedapproach in public health education policies is sociocultural, where human beings are understood within their context; are the agents of their own care, and develop through a constructive process of action-reflectionaction. This empowers people to learn through seeing the need for concrete action based on recognition of their social reality, and targets extreme situations and overcoming contradictions. This education must be based on dialogue, in a horizontal relationship, as an essential aspect for turning into a process that encourages the action-reflection praxis. ${ }^{6}$

Health education for managing and preventing chronic complications of DM in PHC encompasses various systems which are in constant interaction, such as among professionals, family health teams, family health support centers, local management, municipal management, local structure and health policies, in a dynamic process that enables the formation of networks within networks. The complexity of these networks involves constant relations marked by intense interlinks, interrelations, interconnections and multiple possibilities provided by these systems, in an integrative vision that is able to engender numerous possibilities. ${ }^{7}$

In the context of health education for people with DM in $\mathrm{PHC}$, in order to help understand how health professionals organize themselves in this regard, a self-organization concept was sought, in which individuals are self-organizing beings that do not stop self-producing. To this end, they expend energy to maintain their autonomy; they need to extract energy, information, and organization from their environment; and their autonomy is inseparable from this dependence. They are viewed as eco-selforganizing beings. ${ }^{7}$ Therefore, the objective of the present study was to understand how the members of family health teams organize themselves for health education on the management and prevention of chronic complications of DM in $\mathrm{PHC}$.

\section{METHOD}

This was a qualitative study that used complex thought as the theoretical framework and qualitative evaluation, from the perspective of evaluative research, as the methodological framework. Data was gathered using three techniques: interview, observation, and analysis of medical records. The interviews were guided by questions related to care and how it was planned, carried out, monitored and directed by members of family health teams, family health support centers and managers. Observation occurred during individual and collective consultations with health professionals. The medical records examined were selected by family health team nurses, with the prerequisite that they correspond to people with DM receiving care from these professionals. The investigation focused on records involving follow-up, tests ordered, referrals, identification of chronic complications, guidance given, and the quality of the data recorded.

Twenty-five medical records were analyzed and there were 18 observations of care activities with people suffering from DM in PHC. Thirty-eight professionals participated in the study, divided into three sample groups: the first, with 29 professionals from five family health teams; the second with six members from three family health support center teams; and the third group, with two directors of basic health units and one municipal manager. The interviews lasted from 30 minutes to 2.5 hours and were recorded using electronic audio devices. The data was collected in a city in southern Brazil from December 2013 to May 2014.

For the inclusion of study participants, data from the Basic Care Information System was assessed; family health teams with the largest number of people with DM were sought; and other professionals (family health support centers and managers) were the references for the family health team professionals. Family health teams with incomplete staff, especially those missing physicians and nurses, were excluded.

Triangulation of the data collected was used in the data analysis ${ }^{8}$; and directed analysis ${ }^{9}$ with protocols established by the Ministry of Health for caring for people with DM, more specifically for health education, as a reference..$^{10,2}$

After transcription of the interview data, ATLAS.ti software, version 7.1.7, with license number 58118222, was used, in addition to the grounded theory analytical technique ${ }^{11}$, which encompasses the open and axial coding stages.

For the medical record data analysis, the data was entered into a spreadsheet designed by the researchers for this purpose, and the observation data was recorded in a field log. These two sources were constantly analyzed and helped understanding what the participants were saying in relation to health education.

All ethical aspects were respected. The project was approved by the Human Research Ethics Committee of the Federal University of Santa Catarina, under Opinion No. 466.855. To ensure the secrecy of information and the anonymity of the study participants, they were identified by their profession and/or position held, followed by the letter $P$ and a number, corresponding to theinclusion of the interview in the ATLAS.ti software. 


\section{RESULTS}

According to the self-organization of the family health team professionals for health education in management and prevention of chronic complications from DM in PHC, two categories emerged: Shortcomings in health education for people with DM and Potential for health education self-organization.

\section{Shortcomings in health education for people with DM}

This category illustrates the shortcomingsin health education for people with DM in PHC, which are related to various factors. Shortcomings were found in relation to infrastructure, due to lack of space in basic health units for collective educational activities. To carry out collective activities, some family health teams used the reception area of the basic health unit, in the midst of all the other dynamics of users and professionals; other family health teams used small rooms, and many people had to wait in the hallway, which detracts from the nature of collective activities.

Another infrastructure-related weakness was that some basic health units had several family health teams, where the priority established by local managers was rooms for consultations by physicians. Nurses often had no place for seeing patients, which prevented nursing consultations for individual and systematized care for people with DM.

Educational activities for people with DM were not prioritized in the work of health professionals, who did not consider them effective. This lack of importance contrasted with the overimportance assigned to activities centered on medical care, as something agreed on by all the members of the team and management.

[...] we used to give talks before and saw they didn't bear many results and took up a lot of time. So, we stopped the talks to have more time for consultations because sometimes patients listen a little more when they're in the doctor's office, since it's a doctor who is speaking (Physician-P28).

During collective activities, many nurses organized themselves in the face of disturbances in the operationalization of care dynamics, performing the same activities as nursing aides - characterized by checking of vital signs, anthropometric measurements and blood glucose levels, in addition to entering this data into computerized systems.

In relation to individual consultations with medical professionals, the average time established for people with DM was the same as for other people, ranging from 15 to 20 minutes. However, every professional had a personal dynamic for carrying out their activities. Among the consultations that were observed, no time was allotted toproviding guidance, in the form of educational actions for these people. Neither were there any notes in the medical records of guidance given in the past.
In terms of home visits, missed opportunities for educational activities by medical professionals and nurses were also identified, as noted in the following report:

[...] the doctor is very nice. In the homes, the doctor always hands out the papers that were printed with the medication, but the problem is that most of the elderly people don't know how to read. So, I have to go and explain (Community Health Worker-P26).

Another shortcoming detected involved the interrelations and interactions amongPHC professionals. According to the study participants, there was a lack of dialogue in various situations, and among different $\mathrm{PHC}$ professionals, which had a negative impact on care, to the detriment of users of the health service and, consequently, in the context of health education.

The doctor does not give me any feedback on the patients she sees or whether she detected anything in the consultation. She doesn't realize it, that she should come and say: "You know so-and-so? We need to keep an eye on her - she's decompensated. "That doesn't happen. So, dialogue is necessary at times (Nurse-P4).

\section{Potential for health education self-organization}

This category addresses potential opportunities for changes to improve health education for people with $\mathrm{DM}$ in $\mathrm{PHC}$, as pointed out by the study participants.

The group of people with DM who used insulin, called the "insulin-dependent group" by the participants, was mentioned by only one family health team. However, there was no program or plan to promote emancipatory health education among all the participants of the group to prepare people with DM for self-care. There were occasional talks to pass on information, but it was noted that educational actions were not the main activity of this group, despite the fact that talks could be considered a potential channel for educational activities.

Walking groups were organized by some family health teams and the entire population of the area was invited to join in. Theygenerally occurred once a week, lasted approximately an hour, and were led by community health workers. When a nursing professional was present, they checked the blood pressure of the participants and sometimes the blood glucose of people diagnosed with DM. When a professional from the family health support center was present, guidance was given on lifestyle changes. Despite the low adherence of people to this type of intervention - 10 to 30 participants per family health team -it provided a potential opportunity for educational activities to help prevent chronic complications from DM in PHC.

One of the family health teams that participated in the study started implementing a self-care support group for people with $\mathrm{DM}$, in an effort to improve their understanding and responsibility 
to exercise care for maintaining healthy lifeconditions. This initiative was a partnership between the family health team and family health support center. However, it was launched and directed toward a very small number of people considered to be at high risk, but the idea is to replicate it to more people in a short period of time.

The doctor saw those that had more risks. He separated the most serious patients and invited them to participate, 11 of whom agreed. This group will meet every 15 days for four months, and after this we will recruit other patients to keep it going (Nurse-P27).

Another potential area for health education for people with DM that was pointed out by the study participants was the need for these professionals to improve the instructions given during individual and collective consultations to people with DM, with a focus on prevention of chronic complications from the disease.

\section{DISCUSSION}

The main finding of the present study was that, in the context assessed, health education for people with DM was set withina context of deficiencies and limitations that interfered directly with educational activities and hindered their effectiveness.

Deficiencies related to infrastructure, such as lack of space in basic health units for carrying out collective activities, was viewed by study participants as a limitation for educational activities, resulting in care based on the hegemonic medical model. Problems related to the architectural conditions of basic health units were also identified in another study conducted in primary health care. These conditions were cited as one of the reasons that led to the health service organizing the provision of care around physicians. ${ }^{12}$

Health education activities and actions aimed at enabling people with DM to provide self-care and manage the disease were not very significant in this care context. This situation contrasts withthe recommendations of studies and policies, where there is a consensus that all educational actions should seek to empower people to develop individual skills to cope with the pathological process and expand possibilities of disease control, prevention of complications, rehabilitation and making decisions that are conducive to a healthy life. ${ }^{13,1,5}$

Besides enabling a critical outlook and greater participation and autonomy of people fordealing with the multiple facets experienced in their health/disease processe ${ }^{14}$, educational activities should strive for comprehensive care co-responsibility. They should be structured around actions that include health education supported by educational paradigms that value the humanistic perspective and consider individuals to be biological, psychic, affective, rational beings, as well as historical, social, dialectical beings. This education should situate them within and not separate them from their universe. ${ }^{6,7}$ Health professionals who work with people with $\mathrm{DM}^{15-17}$ in different cultures and nationalities should be expected to apply these concepts and search for new educational possibilities. ${ }^{18}$

In view of the limitations and shortcomingsin health education in PHC, and due to concerns about the absence of this practice, a study argues that the implementation of health education as an emancipatory practice based on dialectics and reflection requires professionals to be trained. ${ }^{19} \mathrm{In}$ this study, the absence of professional nurses was noted, primarily because they did not engage in nursing consultations for people with DM and due to their lack of involvement in activities carried out for this public. A study conducted with people with type $2 \mathrm{DM}$ also identified lack of training of health professionals, which was reflected in superficial care that did not prepare patients for the disease self-management. ${ }^{20}$

In this study, when professionals recognized group activities, they were marked by the absence of relations and interrelations among the people present, and even between the people with DM and health professionals. However, collective educational practices that promote communicational integration between health professionals and users, and among users, are essential for self-care maintenance, construction of new meanings about the disease, and changes in the conception of the health/disease process among participants, which converges with health education policy guidelines. ${ }^{21-23}$

In the context of DM and the prevention of chronic complications, considering the complexity of the disease and its treatments, actions involving health education are extremely important for people to successfully control the disease. $., 24,25$ Furthermore, appropriation of knowledge is not based on the amount of information accumulated, but on the socialization of knowledge in a contextualized way. ${ }^{7}$

In light of the shortcomings presented, guidance should be considered as an instrument of health education, essential for users to be able to take care of their condition, as recognized by DM health policies and many other complementary policies ofthe Brazilian public health system. ${ }^{2}$

National policies and international consensuses target this cause, establish needs and indicate the best ways for health professionals to act in a participatory manner, with practices that facilitate applicability of care that is able to guarantee the rights of people with DM so they can obtain the necessary knowledge for self-care, with autonomy and empowerment. In so doing, they will be able to make choices responsibly in relation to the multiple and complex treatments required by the disease. ${ }^{1,2,5}$

The results also indicated the presence of conflicts between professionals within the primary health care context. This demonstrates that human relations are one of the biggest challenges of teamwork, where the individual behavior of each member ends up becoming the main barrier to the team integration ${ }^{26}$ and the development of interdisciplinarity.

In terms of the potential for health education selforganization, the results indicated that health professionals can promote improvements in the care of people with DM in $\mathrm{PHC}$, primarily through groups with different methodologies. 
However, it was observed that this practice was only offered to a small number of the collectivity; the methodological strategies for carrying out activities that included health education actions were timid and modest; not all the members of the family health teams were involved in the pursuit of comprehensive care, with the participation of all the social actors; and there was no broader goal for developing competences, co-responsibility and coparticipation, aimed at encouraging and developing autonomy in people for self-care and conscious choices.

The complexity in the organization of systems involves disorder as a paradigm of their organization. However, complexity can find basic explanations in certain principles considered simple. ${ }^{7}$ Although the study identified disorders in DM health education and difficulties of the actors involved in carrying out educational activities that differ from traditional types, the study participants pointed out potential areas for establishing order, not reducing it to an organization but associating it with the current organization. This is because self-organization means adapting to new things. Its adaptive flexibility is expressed by inventive and diversified strategies that replace rigid behaviors, with the idea of dynamicity and a system open to change. ${ }^{7}$

In this study, in view of all the difficulties and disorders, and the few signs of order in the context of health education for people with DM in PHC, for the self-organization of health professionals who make up the Family Health Strategy, it should be taken into account that this context is permeated with multiple complex situations, which extend far beyond the actions of these professionals. It includes actions that are part of a whole, which cannot always be supplied by the sum of the parts, since they are reflections of a set of intervening and often unfavorable situations, such as managers assigning little value to existing policies and not promoting themeansfor them to be operationalized, but rather focusing their actions and behaviors on reinforcing a healthcare model that is still curative, individual and prescriptive.

\section{CONCLUSION}

Self-organization for the health education of people with DM in PHC is set within a multifaceted context, with barriers to its implementation. The data indicates that this context needs to be viewed in new ways and requires greater involvement of health professionals and managers, along with the frameworks that support it. Reconstruction is needed in the singular and plural realm, with a focus on the multiple dimensions of health education and the correlation of this issue with DM.

Health education must be restored and assigned importance as a fundamental work tool to assist people with DM. This is justified by all the specificities of the disease and the demands generated by them, for effective and comprehensive control that is able to prevent chronic complications.

With respect to nursing, the study reveals the need for greater involvement of these professionals with DM health education, which should be based on a dialogic and emancipatory model to guide the daily clinical practices of people with DM. The hope is that these professionals will have new outlooks that will lead them to a new order, which must include improvements in the relations and interrelations among the various professionals, who are the social actors; in addition to promoting improvements in dialogic communication in all the care and management activities involved with this care.

\section{REFERENCES}

1. American Diabetes Association. 14. Diabetes Advocacy. Diabetes Care [Internet]. 2016 Jan; [cited 2017 Dec 14]; 39 Suppl 1:S105-6. Available from: https://www.ncbi.nlm.nih.gov/pubmed/26696672

2. Ministério da Saúde (BR). Cadernos de Atenção Básica. Estratégias para o cuidado da pessoa com doença crônica: diabetes mellitus. Brasília (DF): Ministério da Saúde; 2013.

3. Barquera S, Campos-Nonato I, Aguilar-Salinas C, Lopez-Ridaura $\mathrm{R}$, Arredondo A, Rivera-Dommarco J. Diabetes in Mexico: cost and management of diabetes and its complications and challenges for health policy. Global Health [Internet]. 2013 Feb; [cited 2014 May 15]; 9:3. Available from: http://www.ncbi.nlm.nih.gov/pmc/articles/ PMC3599194/?report=classic

4. Carolan M, Holman J, Ferrari M. Experiences of diabetes selfmanagement: a focus group study among Australians with type 2 diabetes. J Clin Nurs [Internet]. 2015 Apr; [cited 2017 Dec 14] 24(7-8):1011-23. Available from: https://www.ncbi.nlm.nih.gov/ pubmed/25363710

5. American Diabetes Association. (1) Strategies for improving care. Diabetes Care [Internet]. 2015 Jan; [cited 2017 Dec 14]; 38 Suppl 1:S5-7. Available from: https://www.ncbi.nlm.nih.gov/pubmed/25537709

6. Freire P. Pedagogia do oprimido. $50^{\mathrm{a}}$ ed. Rio de Janeiro: Paz e Terra; 2011

7. Morin E. Introdução ao pensamento complexo. $4^{\text {a }}$ ed. Porto Alegre: Sulinas; 2011

8. Minayo MCS, Assis SG, Souza ER. Avaliação por triangulação de métodos: abordagem de programas sociais. Rio de Janeiro: Editora Fiocruz; 2005.

9. Hsieh HF, Shannon SE. Three approaches to qualitative content analysis Qual Health Res [Internet]. 2005 Nov; [cited 2017 Dec 14]; 15(9):127788. Available from: https://www.ncbi.nlm.nih.gov/pubmed/16204405

10. Ministério da Saúde (BR). Cadernos de Atenção Básica. Diabetes Mellitus. Brasília (DF): Ministério da Saúde ; 2006.

11. Higginbottom G, Lauridsen El. The roots and development of constructivist grounded theory. Nurse Res [Internet]. 2014 May; [cited 2017 Dec 14];21(5):8-13. Available from: https://www.ncbi.nlm.nih.gov/ pubmed/?term=Higginbottom+G\%2C+Lauridsen+El.+The+roots+and +development+of+constructivist+grounded+theory.+Nurse+Res.+201 4+may\%3B21(5)\%3A8-13

12. Magnago $C$, Pierantoni $C R$. Dificuldades e estratégias de enfrentamento referentes à gestão do trabalho na Estratégia Saúde da Família, na perspectiva dos gestores locais: a experiência dos municípios do Rio de Janeiro (RJ) e Duque de Caxias (RJ). Saúde Debate [Internet]. 2015 Jan/ Mar; [cited 2017 Dec 14]; 39(104):9-17. Available from: http://www.scielo. $\mathrm{br} /$ scielo.php?script=sci_arttext\&pid=S0103-11042015000100009

13. LaManna JB, Bushy A, Norris AE, Chase SK. Early and Intermediate Hospital-to-Home Transition Outcomes of Older Adults Diagnosed With Diabetes. Diabetes Educ [Internet]. 2016 Feb; [cited 2017 Dec 14]; 42(1):72-86. Available from: https://www.ncbi.nlm.nih.gov/pubmed/? erm=Early+and+intermediate+hospital-to-home+transition+outcome s+of+older+adults+diagnosed+with+diabetes.+Diabetes+Educ.+201 $6+0 c t \% 3 B 42(1) \% 3 A 72-86$

14. Salci MA, Maceno P, Rozza SG, Silva DMGV, Boehs AE, Heidemann ITSB. Educação em saúde e suas perspectivas teóricas: algumas reflexões. Texto Contexto Enferm [Internet]. 2013 Jan/Mar; [cited 2017 Dec 14]; 22(1):224-30. Available from: http://www.scielo.br/pdf/tce/ v22n1/pt_27

15. Nugent LE, Carson M, Zammitt NN, Smith GD, Wallston KA. Health value \& perceived control over health: behavioural constructs to support Type 
2 diabetes self-management in clinical practice. J Clin Nurs [Internet] 2015 Aug; [cited 2017 Dec 14]; 24(15-16):2201-10. Available from: https://www.ncbi.nlm.nih.gov/pubmed/?term=Health+value+\%26+pe rceived+control+over+health\%3A+behavioural+constructs+to+supp ort+Type+2+diabetes+self-management+in+clinical+practice

16. Huang MC, Hung $\mathrm{CH}$, Stocker J, Lin LC. Outcomes for type 2 diabetes mellitus patients with diverse regimens. J Clin Nurs [Internet]. $2013 \mathrm{Jul}$ [cited 2017 Dec 14]; 22(13-14):1899-906. Available from: https://www. ncbi.nlm.nih.gov/pubmed/?term=Outcomes+for+type+2+diabetes+m ellitus+patients+with+diverse+regimens

17. Martin AL, Lipman RD. The future of diabetes education: expanded opportunities and roles for diabetes educators. Diabetes Educ [Internet] 2013 Jul/Aug; [cited 2017 Dec 14]; 39(4):436-46. Available from: https:// www.ncbi.nlm.nih.gov/pubmed/?term=The+future+of+diabetes+educ ation\%3A+expanded+opportunities+and+roles+for+diabetes+educat ors.+Diabetes+Educ.+2013+jul\%2Faug\%3B39(4)\%3A436-46

18. Wolff K, Chambers L, Bumol S, White RO, Gregory BP, Davis D, et al. The PRIDE (Partnership to Improve Diabetes Education) Toolkit: Development and Evaluation of Novel Literacy and Culturally Sensitive Diabetes Education Materials. Diabetes Educ [Internet]. 2016 Feb; [cited 2017 Dec 14]; 42(1):23-33. Available from: https://www.ncbi $\mathrm{nlm}$.nih.gov/pubmed/?term=The+PRIDE+(Partnership+to+improve+ diabetes+education)+toolkit+development+and+evaluation+of+nove I+literacy+and+culturally+sensitive+diabetes+education+materials

19. Rodrigues D, Santos VE. A educação em saúde na Estratégia Saúde da Família: uma revisão bibliográfica das publicações cientificas no Brasil. J Health Sci Inst [Internet]. 2010; [cited 2017 Dec 14]; 28(4):321. 4. Available from: https://www.unip.br/comunicacao/publicacoes/ics/ edicoes/2010/04_out-dez/V28_n4_2010_p321-324.pdf

20. Gómez-Palencia IP, Castillo-Ávila IY, Alvis-Estrada LR. Uncertainty in Adults with Type 2 Diabetes According to Merle Mishel's Theory. Aquichan [Internet]. 2015; [cited 2017 Dec 14]; 15(2):210-8. Available from: http://pesquisa.bvsalud.org/portal/resource/pt/lil-757232

21. Berry DC, Williams W, Hall EG, Heroux R, Bennett-Lewis T. Imbedding Interdisciplinary Diabetes Group Visits Into a Community-Based
Medical Setting. Diabetes Educ [Internet]. 2016 Feb; [cited 2017 Dec 14]; 42(1):96-107. Available from: https://www.ncbi.nlm.nih.gov/pubm ed/?term=Imbedding+interdisciplinary+diabetes+group+visits+into+ a+community-based+medical+setting

22. Gazzinelli MF, Souza V, Fonseca RMGS, Fernandes MM, Carneiro ACLL, Godinho LK. Educational group practices in primary care: interaction between professionals, users and knowledge. Rev Esc Enferm USP [Internet]. 2015 Mar/Apr; [cited 2017 Dec 14]; 49(2):28491. Available from: http://www.scielo.br/scielo.php?script=sci_arttext\& pid=S0080-62342015000200284

23. Vieira GLC, Cecílio SG, Torres HC. A percepção dos usuários com diabetes sobre a estratégia de educação em grupos na promoção do autocuidado. Esc Anna Nery [Internet]. 2017; [cited 2017 Jun 30]; 21(1):e20170017. Available from: http://www.scielo.br/pdf/ean/ v21n1/1414-8145-ean-21-01-e20170017.pdf

24. Krebs JD, Parry-Strong A, Gamble E, McBain L, Bingham LJ, Dutton ES, et al. A structured, group-based diabetes self-management education (DSME) programme for people, families and whanau with type 2 diabetes (T2DM) in New Zealand: an observational study. Prim Care Diabetes [Internet]. 2013 Jul; [cited 2017 Dec 14]; 7(2):151-8. Available from: https://www.ncbi.nlm.nih.gov/pubmed/?term=A+stru ctured\%2C+group-based+diabetes+self-management+education+( DSME)+programme+for+people $\% 2 \mathrm{C}+$ families+and+whanau+with+t ype+2+diabetes+(T2DM)+in+New+Zealand\%3A+An+observational +study

25. Klein HA, Jackson SM, Street K, Whitacre JC, Klein G. Diabetes selfmanagement education: miles to go. Nurs Res Pract [Internet]. 2013; [cited 2015 May 15]; 2013:15. Available from: http://www.hindawi.com/ journals/nrp/2013/581012/

26. Lanzoni GMM, Meirelles BHS. A rede de relações e interações da equipe de saúde na atenção básica e implicações para a enfermagem. Acta Paul Enferm [Internet]. 2012; [cited 2017 Dec 14]; 25(3):464-70. Available from: http://www.scielo.br/scielo.php?script=sci_arttext\&pid $=$ S0103-21002012000300023 